\title{
Pengaruh Pengendalian Intern Kredit, Likuiditas, dan Ukuran Perusahaan pada Kemampulabaan LPD di Kota Denpasar
}

\author{
Ni Wayan Jessy Janawati ${ }^{1}$ \\ I Dewa Nyoman Badera ${ }^{2}$ \\ ${ }^{1}$ Fakultas Ekonomi dan Bisnis Universitas Udayana (Unud), Bali, Indonesia \\ email: jessyjanawati@yahoocom/+6285738653594 \\ ${ }^{2}$ Fakultas Ekonomi dan Bisnis Universitas Udayana (Unud), Bali, Indonesia
}

\begin{abstract}
ABSTRAK
Perkembangan LPD di Kota Denpasar sepuluh tahun terakhir menunjukkan trend positif baik dari sisi asset, kredit yang disalurkan, maupun laba yang diperoleh. Penelitian ini bertujuan untuk mengetahui pengaruh pengendalian intern kredit, likuiditas, dan ukuran perusahaan pada kemampulabaan LPD di Kota Denpasar. Penelitian dilakukan di seluruh LPD Kota Denpasar. Sampel penelitian diperoleh sebanyak 35 dengan teknik sampling jenuh. Teknik analisis data yang digunakan adalah linier berganda. Tingkat pengendalian intern kredit diukur dengan menyebarkan kuesioner ke masing-masing LPD di Kota Denpasar, likuiditas diukur dengan menggunakan Loan to Deposit Ratio (LDR), ukuran perusahaan dengan Ln total asset, dan kemampulabaan diukur dengan rasio Return on Asset (ROA). Hasil uji F menunjukkan bahwa variabel independen secara simultan berpengaruh pada kemampulabaan LPD di Kota Denpasar. Hasil uji statistik t menunjukkan bahwa pengendalian intern kredit dan likuiditas berpengaruh positif terhadap kemampulabaan, namun variabel ukuran perusahaan tidak berpengaruh pada kemampulabaan.
\end{abstract}

Kata kunci: LPD, kemampulabaan, pengendalian intern kredit, likuiditas, ukuran perusahaan

\begin{abstract}
The development of LPD in Denpasar the last ten years has shown positive trends of assets, credit disbursed, and profit earned. This study aims to determine the effect of internal control of credit, liquidity, and company size on the LPD's. The research was conducted all LPD in Denpasar City. The samples were obtained by 35 with saturated sampling technique. Data were analyzed using multiple linear regression. The level of internal credit control is measured by distributing questionnaires to each LPD in Denpasar City, liquidity measured using LDR, firm size with Ln total assets, and profitability measured by ROA ratio. F-test results show that independent variables simultaneously affect the LPD's profitability in the city of Denpasar. The result of statistical t-test shows that internal control of credit and liquidity have positive effect on profitability, but firm size variable has no effect on profitability.
\end{abstract}

Keywords: LPD, profitability, internal credit control, liquidity, company size

\section{PENDAHULUAN}

Masyarakat Bali sebelum membentuk Lembaga Perkreditan Desa (LPD) memang sudah memiliki tradisi pengelolaan keuangan secara bersama-sama yang disebut pacingkreman. Tradisi inilah yang menimbulkan inisiatif Prof. Dr. Ida Bagus 
Ni Wayan Jessy Janawati dan I Dewa Nyoman Badera. Pengaruh...

Mantra, Gubernur Bali saat itu untuk membentuk LPD di tahun 1984. Tujuannya adalah untuk mendirikan lembaga yang mampu bersaing dengan sektor perbankan, tetapi diintegrasikan ke dalam warisan budaya Bali berupa desa pakraman.

Berdasarkan Peraturan Gubernur Bali Nomor 11 Tahun 2013, Lembaga Perkreditan Desa (LPD) adalah lembaga keuangan milik desa pakraman yang melaksanakan kegiatan usaha di lingkungan desa dan untuk krama desa. Fungsi utama LPD adalah menghimpun dana masyarakat melalui tabungan yang terarah dan mengalokasikan kembali dana tersebut dengan menggerakan semua sumber daya yang tersedia sehingga mencapai tingkat kemampulabaan yang memadai. Kemampulabaan merupakan kemampuan LPD untuk memperoleh laba dan potensi untuk memperoleh penghasilan pada masa yang akan datang. Menurut Putra dan Wirajaya (2013) besar kecilnya peranan LPD dalam menunjang pembangunan desa adat di Kota Denpasar tergantung dari kemampuan LPD itu sendiri dalam mengelola usahanya. Tingginya tingkat kemampulabaan menggambarkan kinerja yang baik dari sebuah LPD, yang berarti bahwa LPD telah beroperasi secara efektif dan efisien serta memungkinkan untuk memperluas usahanya.

Kegiatan utama LPD di Kota Denpasar adalah pemberian kredit, dan merupakan sumber pendapatan utama bagi LPD. Kredit merupakan aktiva lancar yang relatif likuid dan merupakan sumber pendapatan utama bagi LPD, mengalir dan masuk setiap saat, mudah dipindah tangankan dan mudah diselewengkan. Mengingat penyaluran kredit ini tergolong aktiva produktif atau tingkat 
penerimaannya tinggi maka konsekuensi penyaluran kredit mempunyai risiko yang cukup tinggi. Untuk itu kredit harus dikelola secara baik dengan menggunakan prinsip kehati-hatian agar tidak mengganggu kelancaran operasional perusahaan. Pengendalian intern kredit yang baik diperlukan sehingga kredit yang diberikan dapat kembali tepat waktu bersama dengan bunganya.

Kredit yang disalurkan oleh LPD perlu dikendalikan untuk menjaga likuiditas LPD. Likuiditas LPD dapat diukur menggunakan Loan to Deposit Ratio (LDR). Besar kecilnya rasio LDR suatu LPD akan mempengaruhi kemampulabaan LPD. Semakin tinggi LDR akan semakin tinggi tingkat keuntungan perusahaan karena penempatan dana berupa kredit yang diberikan semakin meningkat, sehingga pendapatan bunga akan semakin meningkat pula (Setiadi, 2010).

Ukuran LPD merupakan salah satu tolak ukur bagi LPD dalam mencapai keuntungan (Meitasari, 2016). Semakin besar ukuran LPD, maka semakin banyak sumber daya dan dana yang dapat digunakan oleh LPD, khususnya dalam penyaluran kredit untuk nasabah. Logaritma dari total aktiva lancar dan tidak lancar yang dimiliki LPD pada akhir tahun buku dapat digunakan untuk mengukur variabel ukuran LPD. Menurut Sudarmadji dan Sularto (2007) total asset dipilih menjadiproksi dalam meneliti ukuran perusahaan karena total asset lebih stabil dan juga representatif dalam menunjukkan ukuran perusahaan jika dibandingkan dengan penjualan serta kapitalisasi pasar yang sangat dipengaruhi oleh permintaan dan penawaran. 
Ni Wayan Jessy Janawati dan I Dewa Nyoman Badera. Pengaruh...

LPD dalam kurun waktu kurang lebih 20 (dua puluh) tahun telah memperlihatkan perkembangan yang pesat, dari sisi jumlah, perkembangan usaha, ataupun labanya. Terdapat 35 buah desa pakraman di Kota Denpasar dan keseluruhan LPD di Kota Denpasar berjumlah 35 LPD, ini berarti seluruh desa pakraman yang ada di Kota Denpasar mempunyai LPD. Selama sepuluh tahun terakhir, LPD di Kota Denpasar mengalami perkembangan yang baik serta menunjukkan trend positif jika dilihat dari segi aktiva, penyaluran kredit, ataupun perolehan laba. Tabel 1 berikut ini menunjukkan perkembangan LPD Kota Denpasar tahun 2007-2016.

Tabel 1.

Perkembangan LPD Kota Denpasar Tahun 2007-2016 (dalam Ribuan Rupiah)

\begin{tabular}{ccccc}
\hline Tahun & Aktiva & $\begin{array}{l}\text { Pinjaman } \\
\text { Diberikan }\end{array}$ & $\begin{array}{l}\text { Dana Pihak } \\
\text { Ketiga }\end{array}$ & Laba \\
\hline 2007 & 286.908 .372 & 188.813 .185 & 240.229 .635 & 13.328 .681 \\
2008 & 357.977 .099 & 234.497 .151 & 221.386 .343 & 15.512 .438 \\
2009 & 436.333 .652 & 314.944 .623 & 347.959 .885 & 19.157 .225 \\
2010 & 525.290 .553 & 393.788 .974 & 420.091 .136 & 24.528 .170 \\
2011 & 666.944 .950 & 475.600 .009 & 540.339 .913 & 29.989 .467 \\
2012 & 839.471 .857 & 598.184 .174 & 686.121 .066 & 36.374 .419 \\
2013 & 1.007 .327 .469 & 775.006 .137 & 821.769 .030 & 45.290 .266 \\
2014 & 1.179 .967 .305 & 933.462 .026 & 951.617 .017 & 55.667 .022 \\
2015 & 1.383 .896 .375 & 1.109 .998 .494 & 1.112 .860 .941 & 64.996 .208 \\
2016 & 1.625 .610 .986 & 1.244 .928 .476 & 1.311 .639 .046 & 70.217 .525 \\
\hline Sumber: LPLPD Kota Denpasar, data diolah, 2017 & &
\end{tabular}

Tahun 2016 LPD di Kota Denpasar dengan asset Rp 1,6 triliun dan laba mencapai Rp 70 Miliar dialokasikan sebagai cadangan modal sebesar 60\%, untuk dana pembangunan desa 20\%, untuk jasa produksi sebanyak 10\%, dana pemberdayaan sejumlah $5 \%$ serta dana sosial 5\%. Hal ini menunjukkan bahwa LPD di Kota Denpasar turut berperan dalam permodalan masyarakat serta turut 
berperan dalam pengembangan desa adat di Kota Denpasar. Berdasarkan fakta dan pemaparan sebelumnya, peneliti ingin mengetahui faktor yang menyebabkan meningkatnya kemampulabaan LPD. Apakah trend positif tersebut merupakan dampak dari meningkatnya pengendalian intern kredit, likuiditas, dan ukuruan perusahaan yang akan mempengaruhi tingkat kemampulabaannya.

Rumusan masalah yang diajukan adalah apakah pengendalian intern kredit, likuiditas, dan ukuruan perusahaan berpengaruh pada kemampulabaan LPD di Kota Denpasar. Tujuan penelitian yaitu mendapatkan bukti empiris atas pengaruh pengendalian intern kredit, likuiditas, ukuran perusahaan pada kemampulabaan LPD di Kota Denpasar. Kegunaan penelitian ini diharapkan mampu memberikan masukan, informasi, acuan dan referensi kepada manajemen atau pengurus LPD mengenai faktor-faktor yang dapat mempengaruhi kemampulabaan LPD.

Teori Sinyal (signaling theory) yang digunakan dalam penelitian ini menjelaskan bahwa sinyal-sinyal keberhasilan ataupun kegagalan LPD harus disampaikan kepada krama desa untuk mengurangi asimetri informasi manajemen (LPD) dengan pihak lain atau luar (krama desa). Informasi akurat, lengkap, relevan, dan tepat waktu menjadi sebuah sinyal yang diberikan LPD kepada pihak eksternal. LPD dapat meningkatkan kepercayaan masyarakat dengan mengurangi asimetri informasi, salah satunya dengan memberikan sinyal dalam bentuk informasi keuangan yang terpercaya agar ketidakpastian tentang masa depan LPD berkurang.

Baiknya laporan kinerja LPD dapat meningkatkan kepercayaan pihak luar (krama desa) dalam mengambil keputusan investasi, kredit serta keputusan 
Ni Wayan Jessy Janawati dan I Dewa Nyoman Badera. Pengaruh...

lainnya yang sejenis, sehingga berdampak terhadap meningkatnya laba. Sistem pengendalian intern kredit yang baik diperlukan LPD untuk menjaga kredit yang disalurkan tetap lancar dan produktif, sehingga LPD dapat menghasilkan laba. Semakin efektif sistem pengendalian intern kredit LPD maka kredit bersama bunganya dapat dikumpulkan kembali berdasarakan perjanjian yang telah disepakati antara nasabah dengan pihak LPD. Ini berarti pengendalian intern kredit yang baik akan berpengaruh terhadap kemampulabaan LPD. Penelitian yang dilakukan Dewi (2013) dan Hayati (2005) menemukan bahwa pengendalian intern kredit berpengaruh positif terhadap kemampulabaan.Berdasarkan hal itu, hipotesis pertama dalam penelitian ini yaitu:

$\mathrm{H}_{1}$ : Pengendalian intern kredit berpengaruh positif pada kemampulabaan LPD di Kota Denpasar.

Likuiditas memperlihatkan kemampuan LPD dalam melaksanakan pemenuhan kewajiban jangka pendeknya. Likuiditas LPD harus mencukupi, jangan sampai terlalu kecil karena kebutuhan operasional sehari-hariakan terhambat. Likuiditas sebaiknya tidak terlalu besar karena hal ini bisa menyebabkan turunnya efisiensi kinerja LPD. Menurut teori The Liability Management serta penjelasan Setiaji (2011) tentang likuiditas, disampaikan bahwa semakin tinggi rasio LDR maka memberikan indikasi meningkatnya kemampuan likuiditas sehingga risikonya menjadi turun. Oleh karena itu, dengan meningkatnya likuiditas LPD akan berdampak pada meningkatnya kemampulabaan. Penelitian yang dilakukan Hidayat (2016), Ferdian (2016), Prasanjaya (2013), Dasih (2014), dan Agustiningrum (2013), menemukan bahwa 
likuiditas berpengaruh positif terhadap kemampulabaan. Jadi hipotesis kedua yang diajukan adalah:

$\mathrm{H}_{2}$ : Likuiditas berpengaruh positif pada kemampulabaan LPD di Kota Denpasar. Salah satu tolak ukur suatu LPD dalam memperoleh labaadalah ukuran LPD. Ukuran LPD dapat dinilai dari total assets yang dimiliki oleh LPD. Semakin besar ukuran LPD, maka semakin banyak sumber daya dan dana yang dapat dipergunakan dalam kegiatan usaha, khususnya untuk penyaluran kredit kepada nasabah. Penelitian tentang pengaruh ukuran perusahaan pada kemampulabaan telah dilakukan Koriawan (2014), Ferdian (2014), serta John dan Adebayo (2013) yang mendapatkan bukti empiris mengenai ukuran perusahaan yang berpengaruh positif pada kemampulabaan. Hipotesis ketiga yang diajukan dalam penelitian ini adalah sebagai berikut:

$\mathrm{H}_{3}$ : Ukuran perusahaan berpengaruh positif pada kemampulabaan LPD di Kota Denpasar.

\section{METODE PENELITIAN}

Penelitian ini membahas tentang pengaruh pengendalian intern kredit, likuiditas, dan ukuran perusahaan terhadap kemampulabaan. Pendekatan kuantitatif digunakan pada penelitian ini karena menggunakan laporan keuangan dari Lembaga Perkreditan Desa di Kota Denpasar. Penelitian dilaksanakan pada seluruh LPD yang terdapat di wilayah Kota Denpasar dan menggunakan pendekatan asosiatif. Objek penelitiannya adalah pengendalian intern kredit, likuiditas, ukuran perusahaan dan kemampulabaan LPD di Kota Denpasar. Penelitian menggunakan kemampulabaan sebagai variabel dependen serta 
Ni Wayan Jessy Janawati dan I Dewa Nyoman Badera. Pengaruh...

pengendalian intern kredit, likuiditas dan ukuran perusahaan sebagai variabel independen.

Secara sistematis, kerangka konseptual penelitian yang digunakan penelitian ini dapat digambarkan dan dijelaskan dari Gambar 1 berikut ini:

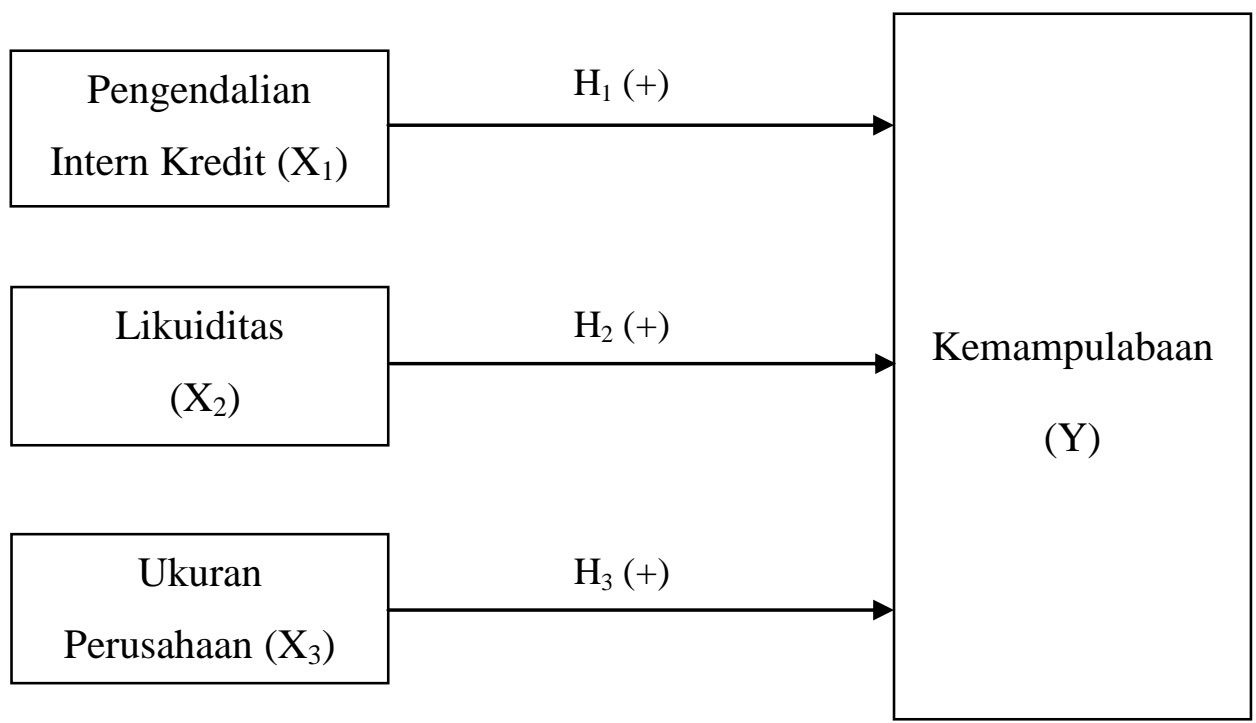

Gambar 1. Kerangka Konseptual Penelitian

LPD di Kota Denpasar dipilih menjadi lokasi penelitian karena seluruh desa pakraman di kota Denpasar telah memiliki LPD dan berdasarkan Tabel 1, LPD di Kota Denpasar menunjukan trend positif selama sepuluh tahun terakhir.

Populasi penelitian ini yaitu seluruh LPD yang terdapat di Kota Denpasar sebanyak 35 LPD, tersebar di kecamatan Denpasar Utara, Denpasar Timur, Denpasar Selatan, serta Denpasar Barat. Metode non-probability sampling dengan teknik sampling jenuh adalah metode penentuan sampel yang digunakan pada penelitian ini. Teknik sampling jenuh merupakan teknik penentuan sampel apabila seluruh anggota populasi dijadikan sampel penelitian. 
Penelitian ini menggunakan data yang diperoleh melalui angket (kuesioner) serta menggunakan data kuantitatif berupa laporan keuangan LPD di Kota Denpasar tahun 2016. Angket (kuesioner) digunakan untuk mengukur pelaksanaan pengendalian intern kredit. Skala likert digunakan untuk mengukur setiap butir pernyataan dalam kuesioner. Sangat tidak setuju (STS) diberi skor 1, tidak setuju (TS) diberi skor 2, setuju (S) diberi skor 3 sedangkan sangat setuju (SS) diberi skor 4. Data kuantitatif berupa laporan keuangan LPD di Kota Denpasar tahun 2016 digunakan untuk mengukur variabel likuiditas, ukuran perusahaan, dan kemampulabaan LPD. Laporan keuangan bersumber dari LPLPD (Lembaga Pemberdayaan Lembaga Perkreditan Desa) Kota Denpasar.

Perbandingan antara kredit yang disalurkan terhadap dana dari pihak ketiga dapat digunakan untuk menilai aspek likuiditas LPD. Rasio kredit yang disalurkan terhadap dana pihak ketiga lebih dikenal dengan istilah Loan to Deposit Ratio (LDR). Suatu LPD dinyatakan likuid bila LPD tersebut bisa memenuhi pengajuan permintaan kredit oleh nasabah tanpa terjadi penangguhan. Indikator likuiditas diukur dengan rumus:

$$
\text { Loan to Deposit Ratio }=\frac{\text { Jumlah Kredit yang Diberikan }}{\text { Total Dana Pihak Ketiga }} \times 100 \%
$$

Ukuran perusahaan merupakan suatu penetapan besar kecilnya perusahaan (Cahyani, 2013). Total asset LPD yang tinggi mengisyaratkan bahwa LPD tersebut termasuk lembaga perkreditan desa yang besar. Sebaliknya, total asset yang rendah mengisyaratkan bahwa LPD tersebut tergolong usaha kecil. Ukuran perusahaan dapat diteliti dengan menggunakan tolak ukur aset atauLn total asset. Perusahaan yang memiliki asset besar akan memanfaatkan sumber daya yang ada 
Ni Wayan Jessy Janawati dan I Dewa Nyoman Badera. Pengaruh...

semaksimal mungkin untuk memperoleh keuntungan LPD yang maksimal sedangkan perusahaan yang memiliki asset kecil akan menghasilkan keuntungan yang relatif kecil sesuai dengan asset yang dimiliki. Rumus ukuran perusahaan dinilai dengan menggunakan logaritma natural, yaitu:

Ukuran Perusahaan $={ }^{10} \log$

Kemampulabaan adalah kemampuan suatu LPD untuk mendapatkankeuntungan atau laba dalam suatu periode tertentu. Return On Asset (ROA) dapat digunakan untuk mengukur kemampulabaan LPD. Rasio ROA dengan membandingkan laba tahun berjalan terhadap total asset digunakan untuk menilai kemampuan LPD dalam mencapai keuntungan secara keseluruhan (Dreca, 2013). Semakin besar ROA suatu LPD, maka tingkat keuntungan yang dicapai dari segi penggunaan aset LPD juga semakin meningkat.ROA dapat dihitung dengan rumus:

$$
\text { Return on Assets }=\frac{\text { Laba Tahun Berjalan }}{\text { Total Asset }} \times 100 \%
$$

Pengumpulan data dilakukan dengan menggunakan metode observasi nonparticipantserta menggunakan analisis regresi linier berganda sebagai teknik analisis datanya. Teknik analisis ini diolah dengan menggunakan aplikasiStatistical Product and Service Solution (SPSS) versi 22. Model regresi penelitian ini, yaitu:

$$
\mathrm{Y}=\alpha+\beta_{1} \mathrm{X}_{1}+\beta_{2} \mathrm{X}_{2}+\beta_{3} \mathrm{X}_{3}+\mathrm{e}
$$

Keterangan :

Y : Kemampulabaan

$\alpha \quad$ : Konstanta atau titik perpotongan dengan sumbu $\mathrm{Y}$, bila $\mathrm{X}=0$

$\beta_{1} \quad$ : Koefisien regresi dari $\mathrm{X}_{1}$ 


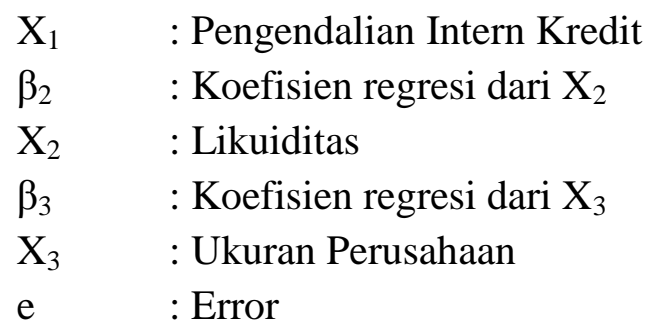

Variabel pengendalian intern kredit diukur dengan menggunakan kuesioner. Skor kuesioner (data ordinal) harus terlebih dahulu diubah dalam bentuk interval sebelum dilakukan analisis regresi. Metode suksesif interval atau Method of Successive Internal(MSI) digunakan untuk mengubah data ordinal. MSI adalah suatu proses perubahan data ordinal menjadi data berbentuk interval. Data yang berbentuk ordinal harus dirubah kedalam data interval karena data ordinal merupakan data yang bersifat kualitatif atau bukan angka sesungguhnya. Data dalam bentuk ordinal memakai angka sebagai simbol dari data kualitatif. Data ordinal pada penelitian ini menggunakan skor angka sebagai simbol data kualitatif, yaitu: skor 1 mewakilikan "Sangat tidak setuju", skor 2 mewakilkan“tidak setuju”, skor 3 mewakilkan "setuju”, dan skor 4 mewakilkan "sangat setuju".

Uji instrumen dibagi menjadi uji validitas dan uji realibilitas yang digunakan untuk menilai instrumen penelitian agar berfungsi dengan baik dan mendapatkan hasil penelitian yang valid serta reliabel.

Instrumen penelitian diuji dengan pengujian validitas untuk mengukur ketepatan, inti, atau arti sebenarnya yang ingin diukur dari instrumen penelitian. Tinggi atau rendah validitas mengindikasikan sejauh mana data yang telah dikumpulkan menyimpang dari gambaran mengenai variabel yang dimaksudkan. 
Ni Wayan Jessy Janawati dan I Dewa Nyoman Badera. Pengaruh...

Kuesioner dinyatakan valid apabila setiap butir pernyataan dapat mengungkapkan sesuatu yang diukur dengan kuesioner. Analisis item digunakan untuk menguji validitas setiap butir pertanyaan dengan cara mengkorelasikan skor dari setiap butir dengan skor total yang merupakan jumlah setiap skor petanyaan. Suatu kuesioner dapat memenuhi syarat minimum apabila korelasi antara butir pertanyaan dengan skor total tersebut bernilai positif dan nilainya lebih tinggi dari 0,30 .

Untuk mengukur derajat ketelitian, ketepatan, serta keakuratan suatu instrumen diperlukan uji reliabilitas, dimana pengujian dilakukan dengan analisis konsistensi dari butir-butir instrumen yang ada. Uji statistik deskriptif merupakan pengujian yang berfungsi untuk menganalisa data secara statistik dengan memberikan deskripsi atau gambaran mengenai mean (nilai rata-rata), nilai minimum, nilai maksimum, serta standar deviasi dari data yang diteliti. Uji statistik deskriptif bertujuan untun menganalisis sampel yang digunakan agar tidak menghasilkan gambaran atau kesimpulan yang digeneralisasikan.

Hasil perhitungan perlu diinterprestasikan dengan tepat dengan melakukan pengujian model regresi atas pelanggarannya pada asumsi klasik. Pengujian asumsi klasik terdiri dari: uji normalitas, uji multikolinearitas, serta uji heteroskedastisitas. Pengujian hipotesis dilakukan dengan uji secara statistik yakni uji kelayakan model (Uji F) dan uji regresi secara parsial (Uji t). Pengujian untuk mengetahui secara bersama-sama pengaruh variabel bebas pada variabel dependen dengan taraf nyata $(\alpha)$ sebesar 5\% dilakukan dengan Uji F. Sedangkan pengujian untuk mengetahui pengaruh signifikansi variabel independen pada variabel 
dependen secara parsial atau individu adalah dengan melakukan uji t dengan taraf nyata $(\alpha)$ sebesar 5\%. Mengukur seberapa kuat hubungan antara variabel independenpada variabel dependen dapat dilihat dari koefisien determinasinya $\left(\mathrm{R}^{2}\right)$. Nilai $\mathrm{R}^{2}$ yang semakin tinggi atau mendekati 1 mengisyaratkan bahwa semakin baik hasil regresi penelitian tersebut.

\section{HASIL DAN PEMBAHASAN}

Penelitian ini dilakukan di seluruh LPD Kota Denpasar. Total LPD yang ada sebanyak 35 LPD yang tersebar di Denpasar Utara, Denpasar Timur, Denpasar Selatan, dan Denpasar Barat. Data penelitian berupa laporan keuangan didapat dari Lembaga Pemberdayaan LPD di Kota Denpasar serta hasil penyebaran kuesioner kepada 35 responden penelitian yaitu seluruh LPD di Kota Denpasar. Kuesioner disebarkan ke masing-masing LPD di Kota Denpasar dengan ketua LPD atau karyawan bagian kredit sebagai perwakilan responden masing-masing LPD. Berdasarkan kuesioner yang disebar, berhasil terkumpul kembali dan diolah sebanyak 35 responden.

Statistik deskriptif bertujuan untuk menyajikan informasi data mengenai variabel penelitian meliputi nilai maksimal, nilai minimum, nilai rata-rata, dan nilai standar deviasi.

Tabel 2.

Hasil Statistik Deskriptif Variabel Penelitian

\begin{tabular}{lrrrrr}
\hline & N & Minimum & Maximum & Mean & $\begin{array}{c}\text { Std. } \\
\text { Deviation }\end{array}$ \\
\hline Peng.InternKredit & 35 & 97,8138 & 117,0106 & 108,105706 & 4,8285191 \\
Likuiditas & 35 & 0,6502 & 1,1663 & 0,909725 & 0,1330766 \\
Uk.Perusahaan & 35 & 14,7132 & 19,0808 & 16,946695 & 1,3265267 \\
Kemampulabaan & 35 & 0,0146 & 0,0808 & 0,042496 & 0,0137751 \\
Valid N (listwise) & 35 & & & & \\
\hline Sumber: Data diolah, 2017 & & & &
\end{tabular}


Ni Wayan Jessy Janawati dan I Dewa Nyoman Badera. Pengaruh...

Berdasarkan Tabel 2, pengendalian intern kredit mempunyai nilai minimum 97,8138 berasal dari LPD Desa Serangan dan maksimum 117,0106 berasal dari LPD Desa Pakraman Penatih Puri. Nilai rata-rata sebesar 108,105706 dengan simpangan baku sebesar 4,8285191, hal ini menunjukkan bahwa data variabel pengendalian intern kredit dapat dikatakan baik karena nilai standar deviasinya lebih kecil dari nilai rata-rata (mean).

Likuiditas yang diukur dengan rasio LDR menunjukkan nilai minimum sebesar 0,6502 atau 65,02\% berasal dari LPD Desa Pakraman Oongan, sedangkan nilai maksimum sebesar 1,1663 atau $116,63 \%$ berasal dari LPD Desa Pakraman Penatih Puri. Nilai rata-rata sebesar 0,909725 atau 90,9725\% dapat disimpulkan bahwa secara statistik tingkat LDR LPD di Kota Denpasar Tahun 2016 sudah berada pada batas aman LDR suatu bank secara umum, yakni antara 78\%-92\% (Peraturan Bank Indonesia Nomor 15/15/PBI/2013) Simpangan baku LDR dapat dilihat dari standar deviasinya yaitu sebesar 0,1330766 atau 13,30766\%, hal ini menunjukkan bahwa data variabel likuiditas dapat dikatakan baik karena nilai standar deviasinya lebih kecil dari nilai rata-rata (mean).

Ukuran Perusahaan yang diukur dengan Ln Total Asset menunjukkan nilai minimum sebesar 14,7132 berasal dari LPD Desa Pakraman Kedua, sedangkan nilai maksimum sebesar 19,0808 berasal dari LPD Desa Pakraman Kesiman. Nilai rata-rata sebesar 16,946695 dengan simpangan baku sebesar 1,3265267, hal ini menunjukkan bahwa data variabel likuiditas dapat dikatakan baik karena nilai standar deviasinya lebih kecil dari nilai rata-rata (mean). 
Tingkat Kemampulabaan yang diukur dengan ROA menunjukkan nilai minimum sebesar 0,0146 atau $1,46 \%$ berasal dari Desa Pakraman Oongan, sedangkan nilai maksimum sebesar 0,0808 atau 8,08\% berasal dari Penatih Puri. Nilai rata-rata sebesar 0,042496 atau 4,2496\% dengan simpangan baku sebesar 0,0137751 atau $1,37751 \%$, hal ini menunjukkan bahwa data variabel likuiditas dapat dikatakan baik karena nilai standar deviasinya lebih kecil dari nilai rata-rata (mean).

Instrumen kuesioner diuji dengan uji validitas untuk mengukur valid tidaknya suatu kuesioner. Sebuah instrumen dianggap valid apabila korelasi antara skor faktor dengan skor total memiliki nilai positif dan memiliki nilai lebih besar dari $0,30(r>30)$. Hasil Uji validitas instrumen memperlihatkan bahwa semua korelasi antara skor faktor dengan skor total memiliki nilai positif dan memiliki nilai lebih besar dari $0,30(r>0,30)$. Oleh karena itu, semua pernyataan dalam kuesioner penelitian mampu mengukur objek penelitian dengan valid dan konsisten. 
Tabel 3.

Hasil Uji Validitas Instrumen

\begin{tabular}{|c|c|c|c|c|c|}
\hline & Instrumen & $\begin{array}{c}\text { Butir } \\
\text { Pertanyaan }\end{array}$ & $\mathbf{R}$ & Sig. & Keterangan \\
\hline \multirow[t]{10}{*}{1} & \multirow{10}{*}{$\begin{array}{l}\text { Jenis Pengendalian } \\
\text { Intern Kredit }\end{array}$} & 1 & 0,363 & 0,032 & Valid \\
\hline & & 2 & 0,683 & 0,000 & Valid \\
\hline & & 3 & 0,477 & 0,004 & Valid \\
\hline & & 4 & 0,359 & 0,034 & Valid \\
\hline & & 5 & 0,624 & 0,000 & Valid \\
\hline & & 6 & 0,352 & 0,038 & Valid \\
\hline & & 7 & 0,375 & 0,026 & Valid \\
\hline & & 8 & 0,337 & 0,047 & Valid \\
\hline & & 9 & 0,333 & 0,051 & Valid \\
\hline & & 10 & 0,323 & 0,058 & Valid \\
\hline \multirow[t]{5}{*}{2} & \multirow[t]{5}{*}{ Analisis Kredit } & 11 & 0,592 & 0,000 & Valid \\
\hline & & 12 & 0,545 & 0,001 & Valid \\
\hline & & 13 & 0,523 & 0,001 & Valid \\
\hline & & 14 & 0,682 & 0,000 & Valid \\
\hline & & 15 & 0,591 & 0,000 & Valid \\
\hline \multirow[t]{9}{*}{3} & \multirow{9}{*}{$\begin{array}{l}\text { Prosedur Umum } \\
\text { Pengendalian Intern } \\
\text { Kredit }\end{array}$} & 16 & 0,465 & 0,005 & Valid \\
\hline & & 17 & 0,425 & 0,011 & Valid \\
\hline & & 18 & 0,367 & 0,030 & Valid \\
\hline & & 19 & 0,466 & 0,005 & Valid \\
\hline & & 20 & 0,397 & 0,018 & Valid \\
\hline & & 21 & 0,498 & 0,002 & Valid \\
\hline & & 22 & 0,375 & 0,026 & Valid \\
\hline & & 23 & 0,558 & 0,000 & Valid \\
\hline & & 24 & 0,375 & 0,000 & Valid \\
\hline \multirow[t]{5}{*}{4} & \multirow{5}{*}{$\begin{array}{l}\text { Struktur } \\
\text { Pengendalian Intern } \\
\text { Kredit }\end{array}$} & 25 & 0,593 & 0,000 & Valid \\
\hline & & 26 & 0,550 & 0,001 & Valid \\
\hline & & 27 & 0,627 & 0,000 & Valid \\
\hline & & 28 & 0,588 & 0,000 & Valid \\
\hline & & 29 & 0,378 & 0,025 & Valid \\
\hline \multirow[t]{3}{*}{5} & Kolektabilitas Kredit & 30 & 0,494 & 0,003 & Valid \\
\hline & & 31 & 0,488 & 0,003 & Valid \\
\hline & & 32 & 0,531 & 0,001 & Valid \\
\hline
\end{tabular}

Sumber: Data diolah, 2017

Reliabilitas merupakan alat untuk mengukur suatu kuesioner yang merupakan indikator dari variabel atau konstruk. Sebuah instrumen dikatakan 
reliabel apabila instrumen yang digunakan mempunyai nilai Alpha Cronbach lebih dari 0,70 (Ghozali, 2007:48).

Tabel 4.

\section{Hasil Uji Reliabilitas}

\begin{tabular}{lccc}
\hline \multicolumn{1}{c}{ Variabel } & $\begin{array}{c}\text { Jumlah } \\
\text { Instrumen }\end{array}$ & $\begin{array}{c}\text { Cronbach's } \\
\text { Alpha }\end{array}$ & Keterangan \\
\hline Pengendalian Intern Kredit & 32 & 0,884 & Reliabel \\
\hline Sumber: Data diolah, 2017 & & &
\end{tabular}

Berdasarkan hasil uji reliabilitas kuesioner, pengendalian intern kreditmenunjukkan koefisien Cronbach's Alpha>0,70. Hal tersebut menunjukkan instrumen pengendalian intern kredit tergolong reliabel dan dapat digunakan.

Uji asumsi klasik merupakan uji yang dilakukan dengan tujuan memastikan hasil yang akan diperoleh telah memenuhi asumsi dasar di dalam analisis regresi. Hasil uji asumsi klasik dalam penelitian ini diantaranya, uji normalitas, uji multikolinearitas, dan uji heteroskedastisitas.

Tabel 5.

Hasil Uji Normalitas

\begin{tabular}{llr}
\hline & & $\begin{array}{c}\text { Unstandardized } \\
\text { Residual }\end{array}$ \\
\hline $\mathrm{N}$ & Mean & 35 \\
Normal Parameters $^{\mathrm{a}, \mathrm{b}}$ & Std. Deviation & 0 \\
Most Extreme Differences & Absolute & 0,00695241 \\
& Positive & 0,1 \\
& Negative & 0,1 \\
Test Statistic & & $-0,082$ \\
Asymp. Sig. (2-tailed) & & 0,1 \\
Sumber: Data diolah, 2017 & & 0,2 \\
\hline
\end{tabular}

Uji normalitas bertujuan untuk menguji apakah model regresi berdistribusi normal atau tidak. Pengujian normalitas data dalam penelitian ini menggunakan uji Kolmogorov-Smirnov. Model regresi yang baik adalah model regresi yang 
Ni Wayan Jessy Janawati dan I Dewa Nyoman Badera. Pengaruh...

berdistribusi normal. Data dikatakan berdistribusi normal apabila tingkat signifikansi menunjukkan nilai lebih besar dari taraf signifikansi $(\alpha)$ sebesar 5\% atau 0,05. Hasil uji normalitas menunjukan nilai Asymp. Sig. (2-tailed) sebesar 0,200. Hasil ini menunjukkan bahwa model persamaan regresi tersebut berdistribusi normal karena nilai Asymp. Sig. (2-tailed) lebih besar dari taraf nyata $5 \%$ atau 0,05 .

Tabel 6.

Hasil Uji Multikolinearitas

\begin{tabular}{|c|c|c|c|c|c|c|c|c|}
\hline \multirow{2}{*}{\multicolumn{2}{|c|}{ Model }} & \multicolumn{2}{|c|}{$\begin{array}{l}\text { Unstandardized } \\
\text { Coefficients }\end{array}$} & \multirow{2}{*}{$\begin{array}{c}\text { Standardized } \\
\text { Coefficients } \\
\text { Beta } \\
\end{array}$} & \multirow{2}{*}{$\mathbf{t}$} & \multirow{2}{*}{ Sig. } & \multicolumn{2}{|c|}{$\begin{array}{l}\text { Collinearity } \\
\text { Statistics }\end{array}$} \\
\hline & & B & $\begin{array}{l}\text { Std. } \\
\text { Error }\end{array}$ & & & & $\begin{array}{l}\begin{array}{c}\text { Toler } \\
\text { ance }\end{array} \\
\end{array}$ & VIF \\
\hline \multirow{4}{*}{1} & (Constant) & $-0,17$ & 0,034 & & $-5,024$ & 0 & & \\
\hline & Peng.Int.Kredit & 0,002 & 0 & 0,66 & 5,069 & 0 & 0,485 & 2,064 \\
\hline & Likuiditas & 0,029 & 0,013 & 0,278 & 2,159 & 0,039 & 0,495 & 2,018 \\
\hline & Uk.Perusahaan & $-0,001$ & 0,001 & $-0,098$ & $-1,052$ & 0,301 & 0,95 & 1,053 \\
\hline
\end{tabular}

Uji multikolinearitas bertujuan untuk menguji apakah terdapat korelasi antar variabel bebas. Model regresi yang baik seharusnya tidak terjadi korelasi diantara variabel bebas. Model yang bebas dari gejala multikolinearitas memiliki nilai tolerance $\geq 10 \%$ atau Variance Inflation Facrtor (VIF) $\leq 10$.hasil perhitungan nilai tolerance menunjukkan tidak terdapat variabel bebas yang memiliki nilai tolerance kurang dari 0,10. Hasil perhitungan VIF juga menunjukkan tidak ada satupun variabel independen yang memiliki nilai VIF lebih dari 10. Jadi dapat disimpulkan bahwa model persamaan regresi bebas dari gejala multikolinearitas. 
Tabel 7.

Hasil Uji Heteroskedastisitas

\begin{tabular}{|c|c|c|c|c|c|c|}
\hline \multirow{2}{*}{\multicolumn{2}{|c|}{ Model }} & \multicolumn{2}{|c|}{$\begin{array}{l}\text { Unstandardized } \\
\text { Coefficients }\end{array}$} & \multirow{2}{*}{$\begin{array}{c}\text { Standardized } \\
\text { Coefficients } \\
\text { Beta } \\
\end{array}$} & \multirow[t]{2}{*}{$\mathbf{t}$} & \multirow[t]{2}{*}{ Sig. } \\
\hline & & B & Std. Error & & & \\
\hline \multirow[t]{4}{*}{1} & (Constant) & 0,011 & 0,019 & & 0,57 & 0,573 \\
\hline & Peng.InternKredit & $4,62 \mathrm{E}-05$ & 0 & 0,055 & 0,221 & 0,826 \\
\hline & Likuiditas & 0,002 & 0,007 & 0,066 & 0,265 & 0,793 \\
\hline & Uk.Perusahaan & $-0,001$ & 0,001 & $-0,234$ & $-1,309$ & 0,2 \\
\hline
\end{tabular}

Sumber: Data diolah, 2017

Uji heteroskedastisitas bertujuan menguji apakah dalam model regresi terjadi ketidaksamaan varians dari residual satu pengamatan ke pengamatan lain. Penelitian ini menggunakan uji glejser untuk mendeteksi gejala heteroskedastisitas. Suatu model regresi dikatakan tidak mengandung gejala heteroskedastisitas apabila tingkat signifikansinya diatas 5 persen atau 0,05 . Hasil Uji heteroskedastisitas menunjukkan bahwa masing-masing variabel memiliki tingkat signifikansi lebih dari 0,05 . Hal ini menunjukkan bahwa model regresi yang digunakan dalam penelitian bebas dari gejala heteroskedastisitas.

Tabel 8.

Hasil Uji F

\begin{tabular}{|c|c|c|c|c|c|c|}
\hline Mode & & $\begin{array}{c}\text { Sum of } \\
\text { Squares }\end{array}$ & Df & $\begin{array}{c}\text { Mean } \\
\text { Square }\end{array}$ & F & Sig. \\
\hline \multirow{3}{*}{1} & Regression & 0,005 & 3 & 0,002 & 30,232 &, $000^{\mathrm{b}}$ \\
\hline & Residual & 0,002 & 31 & 0 & & \\
\hline & Total & 0,006 & 34 & & & \\
\hline
\end{tabular}

Pengujian kelayakan model (Uji F) bertujuan untuk mengetahui seberapa jauh kemampuan variabel independen secara simultan mempengaruhi variabel dependen dengan taraf signifikansi $(\alpha)$ sebesar 5 persen atau 0,05.Diperoleh hasil bahwa nilai koefisien uji $\mathrm{F}$ sebesar 30,232 dengan tingkat signifikansi sebesar 0,000. Oleh karena tingkat signifikansi 0,000 lebih kecil dari taraf signifikansi $(\alpha)$ 
sebesar 5 persen atau 0,05 maka dapat disimpulkan bahwa model penelitian layak digunakan sebagai model regresi. Ini berarti bahwa variabel pengendalian intern kredit, likuiditas, dan ukuran perusahaan secara simultan berpengaruh pada kemampulabaan LPD di Kota Denpasar.

Tabel 9.

Hasil Uji t

\begin{tabular}{|c|c|c|c|c|c|c|}
\hline \multirow{2}{*}{ Mode } & & \multicolumn{2}{|c|}{$\begin{array}{l}\text { Unstandardized } \\
\text { Coefficients }\end{array}$} & \multirow{2}{*}{$\begin{array}{c}\text { Standardized } \\
\text { Coefficients } \\
\text { Beta }\end{array}$} & \multirow{2}{*}{$\mathbf{t}$} & \multirow{2}{*}{ Sig. } \\
\hline & & B & $\begin{array}{l}\text { Std. } \\
\text { Error }\end{array}$ & & & \\
\hline \multirow{4}{*}{1} & (Constant) & $-0,17$ & 0,034 & & $-5,024$ & 0 \\
\hline & Peng.InternKredit & 0,002 & 0 & 0,66 & 5,069 & 0 \\
\hline & Likuiditas & 0,029 & 0,013 & 0,278 & 2,159 & 0,039 \\
\hline & Uk.Perusahaan & $-0,001$ & 0,001 & $-0,098$ & $-1,052$ & 0,301 \\
\hline
\end{tabular}

Pengujian kelayakan model (Uji t) bertujuan untuk mengetahui seberapa jauh kemampuan variabel independen secara individual mempengaruhi variabel dependen dengan taraf signifikansi $(\alpha)$ sebesar 5 persen atau 0,05.model persamaan regresi linear berganda dapat ditulis sebagai berikut.

Kemampulabaan $=-0,170+0,002\left(X_{1}\right)+0,029\left(X_{2}\right)-0,001\left(X_{3}\right)+\varepsilon$

Interprestasi dari variabel yang yang diuji dengan Uji t pada Tabel 7 adalah sebagai berikut:

Tabel 9 variabel pengendalian intern kredit menunjukkan bahwa koefisien regresi sebesar 0,002 dengan tingkat signifikansi sebesar 0,000 lebih kecil dari taraf signifikansi $(\alpha)$ sebesar 0,05 sehingga $\mathrm{H}_{0}$ ditolak dan $\mathrm{H}_{1}$ diterima. Hal ini menunjukkan bahwa variabel pengendalian intern kredit secara parsial berpengaruh positif pada kemampulabaan atau dengan kata lain semakin tinggi pengendalian intern kredit maka semakin tinggi kemampulabaan. 
Berdasarkan hasil uji statistik t pada Tabel9,variabel likuiditas yang diukur dengan rasio LDR menunjukkan koefisien regresi sebesar 0,029. Tingkat signifikansi sebesar 0,039 lebih kecil dari taraf signifikansi $(\alpha)$ sebesar 0,05 sehingga $\mathrm{H} 0$ ditolak dan $\mathrm{H}_{2}$ diterima. Hal ini menunjukkan bahwa variabel likuiditas secara parsial berpengaruh positif pada kemampulabaan atau dengan kata lain semakin tinggi likuiditas maka semakin tinggi kemampulabaan.

Hasil uji statistik t pada Tabel 9, variabel ukuran perusahaan menunjukkan koefisien regresi sebesar -0,001 dengan tingkat signifikansi sebesar 0,301 lebih besar dari taraf signifikansi $(\alpha)$ sebesar 0,05 sehingga $\mathrm{H}_{0}$ diterima dan $\mathrm{H}_{3}$ ditolak. Hal ini menunjukkan bahwa variabel ukuran perusahaan secara parsial tidak berpengaruh pada kemampulabaan.

Tabel 10.

Hasil Uji Koefisien Determinasi $\left(\mathbf{R}^{2}\right)$

\begin{tabular}{rrrrr}
\hline Model & R & R Square & $\begin{array}{c}\text { Adjusted R } \\
\text { Square }\end{array}$ & $\begin{array}{l}\text { Std. Error of } \\
\text { the Estimate }\end{array}$ \\
\hline 1 &, $863^{\mathrm{a}}$ & 0,745 & 0,721 & 0,0072811 \\
\hline
\end{tabular}

Sumber: Data diolah, 2017

Tabel 10 menunjukan nilai adjusted $\mathrm{R}^{2}$ sebesar 0,721 atau 72,1 persen, memiliki arti bahwa setiap 72,1 persen variasi dari variabel dependen, yaitu kemampulabaan dipengaruhi oleh variasi dari variabel independen, yaitu pengendalian intern kredit, likuiditas, dan ukuran perusahaan, sedangkan sisanya sebesar 27,9 persen dipengaruhi oleh faktor-faktor lain yang tidak dimasukkan ke dalam model regresi.

Hasil pengujian ini menunjukkan bahwa pengendalian intern kredit berpengaruh positif pada kemampulabaan LPD, sehingga hipotesis pertama $\left(\mathrm{H}_{1}\right)$ 
Ni Wayan Jessy Janawati dan I Dewa Nyoman Badera. Pengaruh...

dalam penelitian ini diterima. Hal ini berarti semakin tinggi sistem pengendalian intern kredit yang dilakukan oleh Lembaga Perkreditan Desa (LPD), maka semakin tinggi kemampulabaan LPD. Pengendalian intern kredit yang tinggi mengindikasikan bahwa kredit yang disalurkan kepada nasabah dapat ditarik kembali bersama bunganya sesuai perjanjian yang telah disetujui antara kedua belah pihak. LPD memerlukan sistem pengendalian intern kredit yang baik untuk menjaga kredit tetap lancar, produktif, dan tidak macet. Hasil penelitian ini konsisten dengan penelitian yang dilakukan Hayati (2005) yang menemukan bahwa pengendalian intern kredit berpengaruh terhadap kemampulabaan.

Berdasarkan latar belakang, pinjaman yang diberikan kepada nasabah oleh LPD di Kota Denpasar mengalami peningkatan bersamaan dengan kemampulabaannya. Hal ini dikarenakan adanya peningkatan pengendalian intern kredit yang dilakukan oleh LPD serta adanya Peraturan Gubernur Bali tentang Lembaga Perkreditan Desa. Mengingat penyaluran kredit ini tergolong aktiva produktif atau tingkat penerimaannya tinggi maka konsekuensi penyaluran kredit mempunyai risiko yang cukup tinggi. Untuk itu kredit harus dikelola secara baik dengan menggunakan prinsip kehati-hatian agar tidak mengganggu kelancaran operasional perusahaan. Semakin besar proporsi pemberian kreditakan memperbesar jumlah investasi dalam kredit walaupun ini berarti semakin besar resikonya tetapi bersamaan dengan itu juga memperbesar kemampulabaan LPD. Pengendalian intern kredit yang baik diperlukan sehingga kredit yang diberikan dapat kembali tepat waktu bersama dengan bunganya. 
Hasil pengujian ini menunjukkan bahwa secara statistik likuiditas berpengaruh positif terhadap kemampulabaan LPD, sehingga hipotesis kedua $\left(\mathrm{H}_{2}\right)$ dalam penelitian ini dapat diterima. Ini berarti semakin tinggi likuiditas, maka semakin tinggi kemampulabaan LPD. Semakin tinggi LDR akan semakin tinggi tingkat keuntungan perusahaan karena penempatan dana berupa kredit yang diberikan semakin meningkat, sehingga pendapatan bunga akan semakin meningkat pula. Oleh karena itu, dengan adanya peningkatan likuiditas LPD akan menyebabkan meningkatnya kemampulabaan LPD. Hal ini sesuai dengan teori The Liability Management dan penjelasan LDR yang disampaikan Setiaji (2011) bahwa semakin tinggi LDR, maka memberikan indikasi semakin tinggi juga kemampuan likuiditas LPD yang bersangkutan sehingga risiko likuiditas menurun. Hasil penelitian ini mendukung hasil penelitian Setiaji (2011), Agustiningrum (2013) dan Kuntari (2014) yang menunjukkan bahwa likuiditas berpengaruh positif terhadap kemampulabaan LPD.

Hasil pengujian ini menunjukkan bahwa secara statistik, variabel independen ukuran perusahaan yang diukur dengan Ln total asset tidak berpengaruh pada kemampulabaan LPD, sehingga hipotesis ketiga $\left(\mathrm{H}_{3}\right)$ dalam penelitian ini ditolak. Ini terjadi karena beberapa LPD masih belum optimal dalam mengelola aktiva yang dimilikinya untuk menghasilkan laba. Ini terbukti dari besarnya aktiva beberapa LPD yang tidak sebanding dengan besarnya kemampulabaan yang dicapai oleh LPD tersebut. Aktiva yang besar belum tentu menghasilkan laba yang tinggi dikarenakan tingginya asset tetap yang dimiliki 
Ni Wayan Jessy Janawati dan I Dewa Nyoman Badera. Pengaruh...

perusahaan, sehingga kemampuan untuk mencapai laba belum dapat dipastikan (Ferdian, 2014).

Hasil penelitian ini mendukung hasil penelitian dari Prasanjaya (2013), Ferdian (2014), dan Rikalmi (2016), yang menunjukkan hasil bahwa ukuran perusahaan tidak berpengaruh pada kemampulabaan.

\section{SIMPULAN}

Berdasarkan hasil penelitian yang diperoleh melalui pengujian statistik serta pembahasan seperti yang telah diuraikan pada bab sebelumnya, maka dapat disimpulkan bahwa: Pengandalian intern kredit berpengaruh positif pada kemampulabaan Lembaga Perkreditan Desa (LPD) di Kota Denpasar. Hal ini menunjukkan semakin baik pengendalian intern kredit, maka akan meningkatkan kemampulabaan LPD. Pengendalian intern kredit yang baik diperlukan oleh LPD sehingga kredit yang diberikan dapat kembali tepat waktu bersama dengan bunganya. Likuiditas yang diukur dengan LDR berpengaruh positif pada kemampulabaan LPD di Kota Denpasar. Hal ini menunjukkan bahwa semakin besar likuiditas, maka kemampulabaan LPD akan semakin tinggi. Likuiditas yang tinggi menyebabkan tingginya kemampulabaan karena penempatan dana berupa kredit yang diberikan semakin meningkat, sehingga pendapatan bunga akan semakin meningkat pula. Ukuran perusahaan yang diukur dengan menggunakan Ln total asset, secara parsial tidak berpengaruh pada kemampulabaan LPD. Hal ini terjadi karena beberapa LPD masih belum optimal dalam mengelola aktiva yang dimilikinya untuk menghasilkan laba. 
Berdasarkan hasil penelitian dan simpulan di atas, maka saran yang dapat diberikan adalah sebagai berikut: Untuk Lembaga Perkreditan Desa (LPD) perlu mengkaji, mengembangkan, dan menerapkan sistem pengendalian intern kredit dengan lebih baik sehingga kredit macet dapat ditekan serta kredit yang diberikan untuk nasabah dapat ditarik kembali bersama bunganya secara tepat waktu. LPD sebaiknya memperhatikan kemampuan likuiditas untuk melayani pembayaran penarikan-penarikan dana nasabah. Likuiditas menjadi obyek penting bagi LPD karena kepercayaan masyarakat terletak pada mampu tidaknya suatu LPD memenuhi kewajibannya. Penelitian selanjutnya disarankan untuk meneliti LPD di wilayah yang lebih luas. Hal ini diperuntukkan agar hasil dari penelitian dapat digunakan secara lebih luas serta manfaatnya akan lebih bernilai bagi pembaca, khususnya mengenai kemampulabaan Lembaga Perkreditan Desa (LPD) lainnya yang ada di Bali.

\section{REFERENSI}

Agustiningrum, Riski. 2013. Analisis Pengaruh CAR, NPL, dan LDR Terhadap Profitabilitas pada Perusahaan Perbankan. E-Jurnal Manajemen Universitas Udayana, 2 (8).

Asih, Dewi., Adiputra, Adi Pradana., Darmawan, Ari Surya. 2014. Pengaruh Tingkat Perpustakaan Kas, Tingkat Pertumbuhan Jumlah Nasabah dan Ukuran Perusahaan pada Profitabilitas Koperasi Simpan Pinjam (KSP) di Kecamatan Buleleng. E-Journal Universitas Pendidikan Ganesha, 2 (1).

Cahyani, Made Ayu Indra., Ramantha, I Wayan Ramantha. 2013. Pengaruh Aktiva Produktif, Dana Pihak Ketiga, dan Ukuran Perusahaan pada Rasio BOPO. E-Jurnal Akuntansi Universitas Udayana, 2 (3).

Dasih, Kuntari. 2014. Pengaruh Rasio Keuangan Terhadap Return On Assets Perbankan (Studi pada Bank Umum yang Terdaftar di Bursa Efek Indonesia Periode 2007-2013). Skripsi. Universitas Negeri Yogyakarta.

Dewi, Ratih Kumala. 2013. Pengaruh Pengendalian Intern Kredit dan Likuiditas Terhadap Rentabilitas pada BKM Gadang Sejahtera Kelurahan Gadang Kota Malang. Jema, 11(1), pp: 99-108. 
Dreca, Nada. 2013. Determinants of Capital Adequacy Ratio in Selected Bosnian Banks. International University of Sarajevo, pp: 149- 162.

Ferdian, Mario. 2015. Pengaruh BOPO, LDR, NPM, dan Ukuran Perusahaan Terhadap Profitabilitas (Studi Empiris pada Perusahaan Perbankan yang Listed di Bursa Efek Indonesia (BEI) Tahun 2009-2013). Jurnal Universitas Pandanaran Semarang.

Ghozali, Imam. 2007. Aplikasi Analisis Multivariate Dengan Program SPSS. Semarang: Badan Penerbit Universitas Diponegoro.

Hayati, Laili Nurul. 2005. Pengaruh Efektivitas Pengendalian Intern Kredit dan Likuiditas Terhadap Rentabilitas Pada Perusahaan Daerah Bank Perkreditan Rakyat Badan Kredit Kecamatan (PD BPR BKK) di Kabupaten Tegal. Skripsi. Fakultas Ilmu Sosial Universitas Negeri Semarang.

Hidayat, Ahmad. 2016. Does Liquidity and Solvency Affect Banks Profitability? Evidence from Listed Banks in Jordan. International Journal of Academic Research in Accounting, Finance and Management Sciences, 6 (1), pp:35-40.

John, Akinyomi Oladele., Adebayo, Olagunju. 2013. Effect of Firm Size on Profitability: Evidence from Nigerian Manufacturing Sector. Prime Journal of Business Administration and Management (BAM), 3(9), pp: 1171-1175.

Magu, JK., Kibati, P. 2016. Influence of Internal Control Systems on Financial Performance of Kenya Farmers' Association Limited. International Journal of Economics, Commerce and Management, 4 (4), pp: 783-800.

Meitasari, IGA Shinta., Budiasih, IGA Nyoman. 2016. Pengaruh Ukuran Perusahaan, Struktur Modal, dan Loan to Deposit Ratio pada Kinerja Keuangan. E-Jurnal Akuntansi Universitas Udayana, 16 (2), pp: 15161543.

Niresh, J Aloy., Velnampy. 2014. Firm Size and Profitability: A Study of Listed Manufacturing Firms in Sri Lanka. International Journal of Business and Management, 9 (4), pp: 57-64.

Njogo, B O., Ohiaeri, N., Omisakin, J O. 2014. A Panel Data Analysis Of Asset And Liability Management On Performance Of Some Selected Nigerian Commercial Banks. Researchjournali's Journal of Finance, 2 (11), pp: $1-14$.

Novickytė, Lina.,Petraitytė, Indrè. 2014. Assessment of banks asset and liability management: problems and perspectives (case of Lithuania). Procedia Social and Behavioral Sciences, 110, pp: 1082-1093. 
Prasanjaya, A.A. Yogi., Ramantha, I Wayan. 2013. Analisis Pengaruh Rasio CAR, BOPO, LDR Dan Ukuran Perusahaan Terhadap Profitabilitas Bank yang Terdaftar di BEI. E-Jurnal Akuntansi Universitas Udayana, 4(1), pp: $230-245$.

Rikalmi, Ridho Tanso. 2016. Pengaruh Ukuran Perusahaan dan Modal Kerja Terhadap Profitabilitas Perusahaan. Jurnal Politeknik Negeri Batam.

Sari, Ratna Candra., Zuhrohtun. 2006. Keinformatifan Laba di Pasar Obligasi dan Saham: Uji Liquidation Option Hypothesis. Simposium Nasional Akuntansi 9 Padang.

Setiadi, Pompong B. 2010. Analisis Hubungan Spread of Interest Rate, Fee Based Income, dan Loan to Deposit Ratio dengan ROA pada Perbankan di Jawa Timur. Jurnal Mitra Ekonomi dan Manajemen Bisnis, 1 (1), pp: 63-82.

Sudarmadji, Ardi Murdoko., Sularto, Lana. 2007. Pengaruh Ukuran Perusahaan, Profitabilitas, Leverage, dan Tipe Kepemilikan Perusahaan Terhadap Luas Voluntary Disclosure Laporan Keuangan Tahunan. Proceeding PESAT, 2, pp:53-61.

Sujana, I Ketut., et al. 2014. "HARMONI" as Performance Appraisal of Village Credit Institution on Bali, Indonesia. Scientific Research Journal, 11 (7), pp: 1-9.

Wahyuningtyas. 2007. Pengaruh Efektivitas Pengendalian Intern Kredit Terhadap Rentabilitas PD. BPR BKK Di Kabupaten Purbalingga. Skripsi. Universitas Negeri Semarang. 